\title{
Deneyimsel Ürünler ve Araştırma Ürünleri ile İlgili Çevrimiçi Tüketici Yorumları ve Referans Fiyat Bilgisinin Tüketicilerin Satın Alma Davranışları Üzerindeki Etkisi*
}

\author{
Kalender Özcan ATILGAN¹ , Hakan TANIŞMAN² \\ Özet
}

İşletmeleri karlı kılmak için işletme yöneticileri pazarlama programlarında pazarlama süreç ve politikalarının bir karmasını kullanmaktadırlar. Pazarlama karması, dört pazarlama unsuru (4P) için stratejik bir araç olmasına rağmen, tüketici davranışlarını dikkate almayan içe odaklı bir yapıda olması ve bu pazarlama karması elemanları arasında etkileşimin olmaması nedeniyle eleştirilmektedir. Bu bağlamda, bu çalışmanın literatürdeki boşluğu doldurmak için yararlı olacağı düşünülmektedir. Bu çalışmada, çok değişkenli kovaryans analiz (MANCOVA), referans fiyatın (var ve yok), ürün tiplerinin (araştırma ve deneyimsel ürünler) ve çevrimiçi tüketici yorumlarının (az ve çok yorum) satın alma niyeti, çevrimiçi yorum sayısı, algılanan inanılırlık, çevrimiçi yorumlara yönelik genel tutum ve fiyat algısı üzerindeki etkilerini araştıran hipotezleri test etmek için kullanılmıştır. Önceki çevrimiçi satın alma deneyimi ve ilgilenim, analizde kovaryans değişkenler olarak ele alınmıştır. Bu çalışmanın sonunda, incelenen gruplar arasında, satın alma niyeti ve yorum sayısı bağlamlarında istatistiksel olarak anlamlı farklılıklar bulunmuştur.

Anahtar kelimeler:Referans fiyat, araştırma ürünleri ve deneyimsel ürünler, çevrimiçi tüketici yorumları Jel Kodu: M30, M31

\section{The Effects of Online Consumer Reviews and Reference Price Information about Experience and Search Goods on Consumers' Purchasing Behaviors}

\begin{abstract}
To make businesses profitable, a mix of marketing procedures and policies are used by the management of businesses in their marketing programs. In spite the marketing mix is a key strategic combination tool for four marketing elements (4Ps), it is criticized for being internally oriented structure (not considering consumer behavior) and being lack of interaction between each mix element. At this point, it is thought for this study to be useful for filling the gap in the literature. A multivariate analysis of covariance (MANCOVA), was used to test the research hypothesis that investigate the effects of reference price (available vs non-available), product types (search vs experience goods) and online consumer review (high and low reviews) on willingness to buy, number of review, perceived believability, general attitude towards online reviews, and price perception. Prior online purchase experience and involvement were used as covariates in the analysis. At the end of this study, statistically significant differences were found in the context of willingness to buy and number of reviews among the groups examine.
\end{abstract}

Keywords: Reference price, search and experience goods, online consumer reviews

Jel Codes: M30, M31

1. GíRİş

Pazarlama alanında ürünlerin çeşitli özelliklerine göre farklı sinıflandırmalar yapılmaktadır. $\mathrm{Bu}$ sınıflandırmalar içinde özellikle tüketicilerin satın alma kararlarında ürünler hakkında sahip olmak istedikleri bilgi düzeyine göre iki grupta incelenen araştırma ürünleri ve deneyimsel ürünler, bilgi teknolojileri ve özellikle internetin alışveriş işlemlerinde yaygın kullanılmasıyla birlikte dikkat çekmektedir (Klein, 1998; Aggarwal ve Vaidyanathan, 2005; Huang, Lurie ve Mitra, 2009). Araştırma ürünleri, tüketicilerin fazla çaba göstermeden kabul edebildiği veya reddedilebildiği, aynı zamanda birçok bilgiyi

\footnotetext{
* Bu çalışma, Doç. Dr. Kalender Özcan ATILGAN danışmanlığında Hakan TANişMAN tarafından "Deneyimsel ve araştırma ürünlerine yönelik çevrimiçi tüketici yorumları ve fiyat çerçevesinin tüketicilerin satın alma niyetlerine etkisi” başlığıyla hazırlanan yüksek lisans tezi olarak Mersin Üniversitesi Sosyal Bilimler Enstitüsü’nde yayınlanmıştır. 1 Doç. Dr, Mersin Üniversitesi, Erdemli UTIYO, Erdemli / MERSİN, EMAIL: atilgan@mersin.edu.tr ORCID:0000-0003-1482-4505
}

${ }^{2}$ Mersin Üniversitesi, MERSIN, EMAIL:tanisman@mersin.edu.tr ORCID:0000-0002-8016-2274 
değerlendirebildiği ürünlerdir (Ford vd., 1990; Nelson, 1970). Deneyimsel ürünler ise araştırma ürünlerinin aksine gerçekleştirdikleri işlevlerden ziyade uyandırdıkları duygularla değerlendirilir. $\mathrm{Bu}$ iki ürün türü arasındaki temel fark, tüketicinin ürün kalitesini deneyimlemeden önce değerlendirip değerlendiremeyeceğidir. Tüketiciler satın alma kararı vermeden önce bazı etkinliklerde bulunurlar. $\mathrm{Bu}$ etkinlikler arasında, ürün karşılaștırma ve değerlendirme, yakın çevreden veya ürünü kullanan kişilerden bilgi alma, ürünü satan mağazaları gezmek, alınacak ürün ile ilgili araştırmalar yapma gibi etkinlikler yer almaktadır. Tüketicilerin satın alma niyetleri üzerinde önemli yere sahip olan bu etkinlikler tüketici davranışları kapsamında incelenmektedir (Al-Jeraisy, 2008: 47). Tüketiciler satın almak istedikleri ürünü veya hizmeti daha önce alıp kullanan, deneyimleyen diğer kullanıcıların yorumlarını öğrenip bu yorumlar ışı̆̆ında satın alma niyetlerine dönük kararlar verirler. Tüketiciler, satın alacakları ürünlerin özelliklerinin öğrenilmesi ve ürünün satıcısı olan işletmeye olan güvenin sorgulanması gibi bilgilere ulaşabilmek için çevrelerindeki kişiler ile bilgi alışverişi yapar ve onların görüşlerinden yararlanırlar.

Tüketicilerin satın alma niyetlerini etkileyen bir diğer unsur olan fiyat, pazarlama karmasında yer alan dört temel unsurdan biridir. Fiyat, tüketicilerin istenilen miktardaki ürün ve hizmetlere sahip olabilmek için ihtiyaç duydukları parasal miktarın bir oranı olarak açıklanmaktadır (Monroe, 2003: 5). Tüketiciler, gerçekleştirecekleri satın alma işlemi sırasında karşılarına çlkan ürüne veya hizmete ait fiyatları karşılaştırmalar yaparak değerlendirirler. Tüketicilerin yapmış oldukları karşılaştırmalarda uygulanan bazı standartlar vardır ve bunlar pazarlama yazınında referans fiyat olarak adlandırılmaktadır. Referans fiyatın temelinin, tüketicilerin ürüne ait olarak sadece fiyatına odaklanmak yerine belirli bir satın alma standardı oluşturarak göreceli karşılaştırmalar yapmalarına dayandığını ileri sürülmektedir (Thaler, 1985). Yapılan bu karşılaștırmalar sonucunda ürün fiyatı tüketicinin zihnindeki fiyattan yüksekse kayıp, düşükse kazanç algısı meydana getirmektedir (Kahneman ve Tversky, 2013). Başka bir ifadeyle, satışı yapılan bir ürünün fiyatı ile referans fiyatının birbirlerine yakın olması durumunda, tüketicilerin o ürüne karşı olumlu düşündüğünü ve satın alma niyetlerinin arttığını belirtilmektedir (Gijsbrechts, 1993: 120). Referans fiyatın tüketiciler açısından önemli olduğu görülmekte olup pazarlama araştırmalarında tüketicilerin referans fiyat algılarının ürüne ait fiyat sunumundaki değișiklikler ile değiștirilebileceğini ileri sürdügünden (Akhter, 2009: 137), işletmelerin ürünleri ile ilgili fiyatlandırma yaparken tüketicilerin referans fiyat kullandıklarını göz önünde bulundurmaları ve fiyat sunumlarını dikkatli gerçekleştirmeleri gerekmektedir. $\mathrm{Bu}$ bağlamda bu çalışmada, tüketicilerin araştırma ürünleri ve deneyimsel ürünlere yönelik çevrimiçi tüketici yorumları ve dışsal referans fiyatın tüketicilerin satın alma niyeti, çevrimiçi yorum sayısı, algılanan inanılırlık, çevrimiçi yorumlara yönelik genel tutum ve fiyat algısı üzerindeki etkisi incelenecektir.

\section{PAZARLAMADA ARAŞTIRMA ÜRÜNLERİ VE DENEYIMSEL ÜRÜNLER}

Ürün; belirli bir ihtiyaç veya isteği karşılama özelliği bulunan, bir pazarda dikkat çekmek, kullanılmak ya da tüketilmek için sunulan ve değişime konu olan her şey olarak tanımlanabilir (Armstrong ve Kotler, 2007: 201). Pazarlama konusu içinde çok çeşitli ürünler yer aldığından farklı ürünlerin gerektirdiği pazarlama metotları da farklılıklar göstermektedir (Durmaz ve Yardımcıŏglu, 2016: 371). Ürünleri pazarlarken etkili stratejiler planlamak için ürün sınıflarının bilinmesinde fayda vardır (Tek, 1999: 342). Pazarlama yöneticileri ürün sinıflandırması yaparken ürünlerin sahip olduğu farklı özellikleri dikkate alırlar.

Pazarlamada ürün sinıfları üzerinde çalışan Stigler (1961), ürünlerin ilk olarak araştırma özelliğine sahip olduğunu ileri sürmüştür. Daha sonra bu çalışmayı öncül çalışma olarak ele alan Nelson (1970), Stigler'in ortaya çıkarmış 
olduğu kavramları genişleterek ürünleri, tüketicilerin satın alımdan önce ürün kalitesi bilgisini edinme kabiliyetlerine göre araştırma ve deneyim ürünleri olarak sınıflandırmıştır. Dolayısıyla, araştırma ürünleri ve deneyimsel ürün ayrımı, tüketicilerin satın alımdan önce ürünlere ait özellikleri ne ölçüde değerlendirebileceğine dayanmaktadır (Nelson 1970; Nelson, 1974; Huang vd., 2009). Nelson (1974)'a göre bir ürün satın alınmadan önce o ürüne ait baskın olan tüm özellikler biliniyorsa bu ürün bir araştırma ürünü, yine bir ürüne ait bilgiler ve baskın nitelikler doğrudan deneyim olmadan bilinemiyorsa deneyim ürünüdür. Araştırma ürünleri ile deneyimsel ürünler arasındaki ayrım çevrimiçi tüketici davranışının bir özetidir (Nelson, 1970; Nelson 1974).

Araştırma ürünlerine deterjan, köpek maması ve vitaminler örnek gösterilebilmektedir. Valarie ve Bitner (2000) ise satın alımdan önce kolayca değerlendirildikleri için araştırma ürünlerine klyafet ve mobilya gibi ürünleri örnek olarak göstermiștir. $\mathrm{Bu}$ tür ürünler objektif olarak değerlendirilen ve somut özellikleri bulunan ürünlerdir. Tüketiciler bu tür ürünlerin ölçülebilir özelliklere sahip olması nedeniyle seçenekler arasından beklenen performansı en üst seviyeye çıkarmak için seçimler yapabilmektedir. Deneyimsel ürünler ise araştırma ürünlerinin aksine gerçekleştirdikleri işlevlerden ziyade uyandırdıkları duygularla değerlendirilir. Örneğin, filmler, parfümler ve restoran yemekleri bu ürün grubunda yer almaktadır. Bunların dışında tatil paketi veya telekomünikasyon gibi hizmetlerin, müşterilerin satın alımından tüketilmesine kadar olan sürede kalite değerlendirilmesinin tam olarak yapılamayacağından, deneyimsel ürün özellikleri göstermektedir (Hsieh, Chiu, ve Chiang, 2005). Bu tür ürünler öznel, estetik, bütünsel ve duygusal niteliklerle tanımlanan ürünlerdir. Araştırma ürünleri, ürün kalitesini değerlendirmek için önemli özelliklerin, tüketici (ya da başka biriyle) ve ürünle etkileşime girmeden, genellikle keşfedilebilir olduğu ürünlerken; deneyim ürünleri, ürün kalitesiyle ilişkili özelliklerin, ürünle ilgili deneyim yoluyla keşfedilebilecek olanlardır (Daft ve Lengel, 1984; Hoch ve Deighton, 1989; Hoch ve Ha, 1986). Araștırma ürünleri ve deneyimsel ürünlere ait özelliklerin değerlendirilmesi farklı çaba düzeyleri içermektedir ve bilgi arama derinliğinin araștırma ürünlerinden ziyade deneyimsel ürünler için daha büyük olabileceği savunulmaktadır (Ha ve Hoch, 1989). Bu görüşe paralel olarak Mudambi ve Schuff (2010) tüketicilerin deneyimsel ürünlere, arama ürünlerine göre daha fazla zaman harcadıklarını ancak daha az bilgi aradıklarını ileri sürmüştür.

Araştırma ürünlerinin özellikleri (örneğin, fiyat) nesneldir, tanısaldır ve karşılaştırılmaları kolaydır. Oysa deneyimsel ürün özellikleri (örneğin, bir kameranın kullanımı) doğal olarak özneldir, belirsizlik içerir ve değerlendirilmesi zordur (Hoch ve Ha, 1986). Ortaya çıkan bu farklılıklar tüketicilerin bilgi işleme şeklini değiştirebilmektedir. Sheffet (1983)'e göre deneyimsel ürünler son derece soyut ve değerlendirilmesi zor özelliklere sahiptir ve satın aldıktan veya kullandıktan sonra değerlendirilmeleri gereken ürünlerdir. Daha da önemlisi, deneyimsel ürünlerin özellikleri özneldir ve bu nedenle tüketiciler tarafından farklı şekilde algılanmakta ve farklı tutumlar geliştirmelerine neden olabilmektedir.

İnternet hızla gelişirken, bilgi kolayca ve anında dolaşır. Tüketiciler ihtiyaç duydukları bilgileri her yerde ve her zaman arayabilir. $\mathrm{Bu}$ da tüketicilerin ürün bilgileri toplamak için önemli bir zaman harcamasına gerek olmadı̆̆ anlamına gelir. Araştırma ürünleri için tüketiciler, özellik taleplerini minimum yatırımla doğrulamak için arama yapabilir. $\mathrm{Bu}$ anlamda, tüketiciler tüm ürün bilgilerini değerlendirebilir, çünkü ürünler fazla çaba göstermeden doğrulanabilir veya reddedilebilir (Ford vd., 1990; Nelson, 1970). Nelson, tüketicilerin deneyimsel ürünler için satın alma öncesi minimum bilgi araması yaptıklarını, ancak araştırma ürünleri için 
kapsamlı aramalar yaptıklarını savunmaktadır. Bununla birlikte internet'in tüketicilerin başkalarının deneyimlerini öğrenmelerini ve çoğu zaman zor olan ürün bilgilerini toplamalarını sağladığı ileri sürülmektedir (Alba vd., 1997; Klein 1998; Peterson vd., 1997). İnternet hem deneyimsel hem de araştırma ürünleri için önemli bir bilgi kaynağı olarak hizmet etse de tüketicilerin aradığı bilgilerin ve dolayısıyla arama ve seçim yapma biçimlerinin iki ürün türü için farklı olduğu görülmektedir (Ha ve Hoch, 1989; Hoch ve Deighton, 1989; Hoch ve Ha, 1986; Weathers vd., 2007). İnternet özellikle, bilgi toplama ve paylaşma maliyetini düşürür (Hoffman ve Novak, 1996) ve satın alımdan önce ürünler hakkında bilgi edinmek için yeni yollar sunar (Lynch ve Ariely, 2000). Örneğin, içecek satan bir işletme web sitesi aracilığıyla, ürünlerin aromaları ve lezzetleri, ürünler hakkında uzman görüşleri ve tüketici geri bildirimleri gibi geleneksel perakende mağazalarındaki ürün bilgilerinden çok daha zengin bilgiler sağlayabilir (Klein, 1998). Böylece alışveriş yapan tüketiciler, diğer müşterilerden gelen kapsamlı ürün incelemelerini okuyabilir ve bu ürünleri satın almadan önce deneyimleyebilir.

Çevrimiçi ürün yorumları, akademik yayınlar (Kwon ve Sung, 2012) ve endüstriyel raporlar (Huang vd., 2013) tarafından tüketicilerin ürünü değerlendirme ve satın alma kararlarının kilit belirleyicilerinden biri olarak kabul edilmektedir. Çevrimiçi yorumlar, çeşitli ürünlerle ilgili kişilerin tüketim sonrası değerlendirmelerini ve deneyimlerini belgelemektedir. Doğası gereği bu yorumlar nitelik temelli ve deneyime dayalı iki formda sunulmaktadır (Pan ve Zhang, 2011). Nitelik temelli bir ürün incelemesi, ürün özelliklerini incelemeye odaklanır (örneğin, bilgisayar satın almak isteyen bir tüketicinin bir dizüstü bilgisayarın bellek kapasitesini incelemesi). Buna karşılık, deneyime dayalı bir ürün incelemesi, öznel veya duygusal değerlendirmeler içermektedir ve bir ürünün tüketicisinin genel değerlendirmesiyle ilgilidir (örneğin, telefon satın almak isteyen bir tüketicinin bir akıllı telefonun tasarımını incelemesi). Bazı çalışmalar özellik temelli incelemelerin, deneyime dayalı olanlardan daha bilgilendirici olabildiğini savunmaktadır. Çünkü tüketiciler tüketim deneyimlerinden ziyade maddi ürün niteliklerini incelemeye odaklanmaktadır (Mantel ve Kardes, 1999). Bu görüşün aksini savunan çalışmalar ise, tüketim deneyimine dayanan yorumların, tüketicilerin ürünün kullanımını daha iyi görselleştirmelerine yardımcı olduğunu ileri sürmektedir (Franke vd., 2004). EWOM (Electronic Word of Mouth-Elektronik Ağızan Ağıza Pazarlama)'un yeni ürün dağılımındaki kritik rolüne rağmen, çevrimiçi yorumlar tüm ürünler üzerinde benzer etkilere sahip olmayabilir ve çevrimiçi yorumların etkisini hafifleten önemli bağlamsal değişkenler vardır (Sujan vd., 1986). Araştırmacılar, ürün türünün tüketicilerin arama davranışını ve seçimlerini etkileyen bilgi kaynaklarının kullanımını etkilediğini göstermiştir (Lynch vd., 1988). Genel olarak, bir araştırma ürününü değerlendiren tüketicilerin, ürünün belirli özelliklerini değerlendirerek sistematik bir karar verme sürecini kullanma olasılıkları daha yüksektir. Oysa ki bir deneyimsel ürünü satın almayı düşünen tüketiciler, dışsal özelliklerle ilgili olmayan ipuçlarına daha fazla güvenmektedir. Çevrimiçi ortamlarda genellikle araçsal değerlendirme ipuçlarıyla (bir ürünün teknik veya performans yönleri) değerlendirilen araştırma ürünleri için, tüketicilerin ürün özellikleri, işlevleri ve performansları hakkında çok fazla bilgileri vardır. En önemlisi, ürünlerin diğer tüketiciler tarafından değerlendirilmesi, yani ürünlerin derecelendirmeleri belirgin biçimde gösterilir (Ford vd., 1990).

$\mathrm{Bu}$ nedenle, yorumların değeri veya ürünlerin ortalama puanları, tüketicilerin değerlendirmelerini ve araştırma ürünleri için satın alma kararlarını büyük ölçüde etkiler. Çevrimiçi ortamda tüketiciler, çiçekler veya video oyunları gibi ürünleri doğrudan hissedemez veya ürün özelliklerini deneyimleyemez (Cui vd., 2012). Çünkü deneyimsel ürünler tipik olarak duygusal 
değerlendirme ipuçlarıyla (örneğin bir ürünün estetik yönleri) değerlendirilmektedir.

\section{3. ÇEVRIMIÇİ TÜKETÍCI YORUMLARI}

Tüketiciler kullandıkları ürünleri ve hizmetleri övmek, eleştirmek veya deneyimlerini aktarmak için iletişimde bulunurlar (Williams, 2007: 4). Çevrimiçi tüketici yorumlar, hizmet, bir ürün veya işletme ile ilgili tüketiciler tarafından yapılan ve internet aracılı̆̆ ile çok sayıda kişinin ulaşabileceği her türlü olumlu veya olumsuz açıklamalardır (Menkveld, 2013: 9; Aydın, 2014: 15). Çevrimiçi yorumlar; ürünü satın alan, kullanan ve ürüne ait deneyim elde eden tüketiciler tarafından yapılan değerlendirmeleri içerir (Lee vd., 2011: 467). $\mathrm{Bu}$ değerlendirmeler genellikle ürün övgülerini, tüketici şikayetlerini veya belirli bir ürün veya hizmete ait kişisel deneyimleri ifade eder (Stauss, 1997: 28). Yani çevrimiçi tüketici yorumları bir tarafta ürün hakkında bilgi sahibi olmak isteyen diğer tarafta ise o ürünü kullanıp deneyim elde eden ve bu deneyimlere ait bilgileri paylaşan tüketicileri buluşturan iletișim kanallarıdır (Yee, 2006: 11). Kullanıcı odaklı olan bu bağımsız bilgiler yeni bir iletişim türüdür ve popülerliği her geçen gün artmaktadır (Park vd., 2007: 125).

Ürünlere yapılan yorumların sayısı tüketicilerin satın alma niyetini etkileyen önemli bir unsurdur. Yorum sayısının satın alma niyetine etkisi ile ilgili birçok araştırma yapılmıştır. $\mathrm{Bu}$ çalışmaları gerçekleştiren araştırmacılardan Asch (1951) yorum sayısının ürüne ait uygunluk seviyesini etkilediğini ileri sürmektedir. Aynı görüşü destekleyen Campbell ve Fairey (1989) yorum sayısının fazla olmasının ürüne ait satın alma niyetine dair baskıyı arttıran bir faktör olduğundan, az olmasının ise bu baskıyı yaratmadığ görüşünden bahsetmektedirler. Yorum sayısının fazla olmasının tüketicilerin zihinlerinde "diğer birçok tüketici de ürünü satın aldı, bu nedenle popüler bir ürün olabilir" algısı yaratmaktadır (Chevalier ve Mayzlin, 2006: 345). Yapılan başka bir araştırmada bu görüşlerin aksine, yorum sayısındaki fazlalığın tüketiciler üzerinde satın alma niyeti bakımından ağır bir yük oluşturduğundan, tüketicilerin çok fazla olan yorumların hepsini okuyamadığından ve kalan diğer yorumlara dair endişe duyduklarından bahsedilmektedir. $\mathrm{Bu}$ endișenin ürüne dair daha az tatmin ve güvene aynı zamanda da kafa karışıklığına neden olduğu ileri sürülmektedir (Park ve Lee, 2008).

\section{DIŞSAL REFERANS FIYAT}

Fiyatın tüketiciler açısından önemli bir unsur olduğu bilinmektedir. Tüketiciler için fiyat bir malın algılanmasında önemli bir ölçüttür (Cemalcılar, 1999: 212). Çünkü fiyatı bir ürünün kalitesi ile eşdeğer olarak gören tüketiciler vardır. Tüketicilerin satın alacakları ürünlerin fiyatları hakkında beklentileri vardır. $\mathrm{Bu}$ beklentiler kişiye özgüdür ve tüketiciler bu beklentilerinin karşılanmasını isterler (Winer, 1986; Kalwani vd., 1990).

Pazarlamada fiyat konusuna değişik bakış açlarıyla yaklaşılabilmektedir. Fiyata psikolojik yönlü bir bakış açısı ile bakıldığında ön plana davranıșsal fiyatlamanın çıktığı görülmektedir. Davranışsal fiyatlama, satışta olan bir ürünün fiyatının tüketiciler tarafından nasıl algılanıp değerlendirildiğini ve sunulan fiyata gösterdikleri reaksiyonları incelemektedir (Estelami ve Maxwell, 2003: 401-403). Davranışsal fiyatlama alanında incelenmesi gereken önemli konulardan bir tanesi de referans fiyat konusudur (Monroe, 1973). Klasik ekonomik teoriler, pazarlama akademisyenleri ve satıcılar geleneksel olarak, geçmiş fiyatların tüketicilerin sonraki kararları ve ürün satın alma kararları için bilişsel referans noktası olarak hizmet ettiklerini varsaymaktadır (McGoldrick vd., 1999: 173). Referans fiyat, tüketicilerin geçmiş satın alma tecrübesi ve mevcut satın alma ortamı tarafından şekillendirilen tahmini fiyat beklentisi olarak tanımlanmaktadır (Briesch vd., 1997; Kalyanaram ve Winer, 1995). Monroe (1973) referans fiyatı, satışta olan bir ürünün fiyatının karşılaştırılması için kullanılan standartlar olarak tanımlamaktadır. Başka bir ifadeye göre tüketicilerin zihninde oluşan referans fiyat; deneyimler, önceki satın 
almalar ve gözlemler sayesinde meydana gelmekte ve yapılacak olan yeni satın almalar için karşılaştırmalar yapmak üzere bir standart haline dönüşmektedir (Lowengart, 2002).

İçsel ve dışsal olarak ikiye ayrılan referans fiyatlar bu sınıflandırmanın ikinci aşamasında davranışsal ve yargısal süreçlere ayrılmaktadır (Lowengart, 2002: 152). İçsel referans fiyat, tüketicinin zihninde içsel olarak tecrübe ve muhakeme yoluyla gerçekleşen bir süreci ifade eder. $\mathrm{Bu}$ bağlamda referans fiyat oluşumu süreci, gözlemler ve çevreden gelen bilgiler aracılığıyla gerçekleştirilir (Gabor, 1977). Dıșsal referans fiyat ise, satın alma ortamında mevcut olan karşılaştırmalı fiyat bilgileri, yani tüketicilerin ürün arama sürecinde karşılaşacağl fiyatlar olarak tanımlanabilmektedir. Dışsal referans fiyat, çevreden toplanan bilgilerle oluşmaktadır. Dışsal referans fiyatın oluşturulma kaynağı, farklı mağazalara, üretici reklamlarına ve üreticilerin önerilen liste fiyatlarına dayanmaktadır (Lowengart, 2002). Diğer bir ifadeyle, dışsal referans fiyat tüketicilerin direk olarak görebildikleri fiyatlardır. (Kopalle ve Lindsey-Mullikin, 2003: 226).

\section{ARAŞTIRMANIN YÖNTEMI}

$\mathrm{Bu}$ çalışmada, satın alma davranışlarını etkileyen çeşitli faktörler incelenmiş olup, bu faktörler arasından dişsal referans fiyat, çevrimiçi tüketici yorumları, ürün bilgileri ve ürün türleri üzerine durulmuştur. Bu alanlarda yapılan araştırmalar incelenmiş ve bu bilgiler ışığında tüketicilerin deneyimsel ürünler ve araştırma ürünlerini satın almadan önce referans fiyatın ve çevrimiçi tüketici yorumlarının satın alma davranışı üzerinde farklılık gösterip göstermediği araştırılmıştır. Çalışmanın literatür bölümünde, tüketicilerin satın alma davranışlarını etkileyen çevrimiçi tüketici yorumlarını inceleyen çalışmalar ele alınmıştır. $\mathrm{Bu}$ doğrultuda değişkenler belirlenmiş, hipotezler kurulmuş ve bu hipotezleri test etmek amaciyla veriler elde edilmiştir. Araştırmanın hipotezleri aşağıdaki gibi belirlenmiştir:
H1: Araştırmada incelenen gruplar arasında satın alma niyeti bağlamında farklılık bulunmaktadır.

H2: Araştırmada incelenen gruplar arasında fiyat algısı bağlamında farklılık bulunmaktadır.

H3: Araştırmada incelenen gruplar arasında çevrimiçi yorumlara yönelik genel tutum bağlamında farklılık bulunmaktadır.

H4: Araştırmada incelenen gruplar arasında çevrimiçi yorum sayısı bağlamında farklılık bulunmaktadır.

H5: Araştırmada incelenen gruplar arasında algılanan inanırlık bağlamında farklılık bulunmaktadır.

Gruplar arası deneysel tasarım uygulanmış olan (ürün: deneyimsel ve araştırma; çevrimiçi yorum: az ve çok; referans fiyat: var ve yok) bu çalışmada, grupların fiyat algısı, çevrimiçi yorumlara yönelik genel tutum, çevrimiçi yorum sayısı, algılanan inanılırlık ve satın alma niyeti bakımlarından farklılıkları test etmek amaciyla $(2 \times 2 \times 2) \quad$ MANCOVA yöntemi kullanılmıştır.

Bu çalışma, iki aşamalı olarak yürütülmüștür. Birinci aşamada, araştırmada kullanılacak olan deneyimsel ürünler ve araştırma ürünlerinin hangileri olacağını belirlemek amacıyla, Mersin Üniversitesi Erdemli Uygulamalı Teknoloji ve İşletmecilik Yüksekokulu'nda eğitim görmekte olan 80 öğrenci kolayda örnekleme yoluyla seçilmiştir. Ürünlerin hangilerinin deneyimsel hangilerinin araştırma ürünleri olduğunun belirlenmesinde Weathers vd., (2007) tarafından uygulanan yöntem kullanılmıştır. Ön testte katılımcılara sunulan üçer ürünün, araştırma ve deneyimsel ürün özelliği gösterip göstermediği Weathers vd., (2007)'nin kullandığı ölçekle belirlenmeye çalıșılmıştır. 80 katılımcı rastgele olacak şekilde iki eşit gruba ayrılmış ve birinci gruba deneyimsel ürünlerinin (parfüm, akıllı saat ve restoran) her birini, "Ürünün görünümü önemlidir" "Ürüne dokunmak önemlidir" "Ürünün gösterdiği iyi performans önemlidir" şeklindeki ifadelerle 7'li Likert ölçeğinde değerlendirmeleri istenmiştir. İkinci ön test grubuna ise araştırma ürünlerinin 
(ayakkabı, valiz ve yurtiçi uçak bileti) her birini "Bu ürünü sadece, satıcı ya da üretici tarafından sağlanan ürünün nitelikleri ve özellikleri ile ilgili bilgileri kullanarak değerlendirebilirim." "Bu ürünü, ürün hakkındaki bilgileri okuyarak değerlendirebilirim.” şeklindeki ifadelerle 7'li Likert ölçeğinde değerlendirmeleri istenmiştir. Ön testteki ifadelere verilen cevapların, deneyimsel ürün veya araştırma ürünü niteliklerinin belirlenebilmesi için ortalama değerler alınmış ve her bir ürün için farklılıklar hesaplanmıștır. Ön test bulgularına göre, deneyimsel ürünler arasında anlamlı bir farklılık bulunamamıştır. Fakat çıkan ortalama değerlerine bakılarak deneyimsel ürün niteliği bakımından en yüksek ortalamaya sahip olan akıllı saat $(\overline{\mathrm{X}}=5,77)$ araştırmada kullanılmak üzere seçilmiştir. Benzer şekilde, araştırma ürünleri arasında da anlamlı bir farklılık bulunamadığından araștırma ürünü niteliği bakımından ortalama değerlere bakılarak en yüksek ortalamaya sahip olan valiz $(\bar{X}=4,81)$ çalışmanın araştırma ürünü olarak seçilmiştir. Araştırma ürünleri ve deneyimsel olarak seçilen bu ürünlere (valiz, akıllı saat) ait görsel uyaranlar çevrimiçi alışveriş sitelerindeki ilgili ürün gruplarında çok satılan ürünler kategorisinden seçilerek hazırlanmıştır.

Araştırmada katılımcıların yanıtlaması için oluşturulan anketteki bir başka uyaran olan yorum sayısının ne kadar olması gerektiği konusunda Park ve Lee (2008)'nin çalışmasından yararlanılmıştır. Yorum sayısının tüketicilerin satın alma niyetlerini etkileme düzeyini ölçmek için 56 kişi üzerinde bir araştırma yapan Park ve Lee (2008) katılımcıların internet sitelerinden alışveriş yaparken satın alınacak ürünle ilgili okudukları ortalama yorum sayıları örnek alınarak 3, 9 ve 27 yorumdan oluşan bir anket oluşturmuştur. Anketten alınan cevaplar neticesinde bir ürüne yapılan 3 yorumun yeterli görülmediği, 27 yorumun ise satın alma niyetini etkileyecek düzeyde yeterli olduğu sonucuna varılmıştır. $\mathrm{Bu}$ çalışmadan yola çıkılarak araştırmada katılımcılara ankette gösterilen ürüne ait uyaran yorum sayılarının yeterli olup olmadığının ölçülmesi için ürüne yapılan yorum sayısı 3 ve 27 yorum olarak seçilmiştir. Daha sonra Park ve Lee (2008)'nin çalışmasında yer alan "yorum sayısı" isimli ölçek kullanılarak katılımcılara "Çevrimiçi yorum sayısı fazladır", "Çevrimiçi yorumların miktarı fazlasıyla yeterlidir" şeklindeki ifadeler 7'li Likert ölçeğinde sorularak değerlendirmeleri istenmiştir.

Tüketiciler ürün satın almalarda ilgili ürünün fiyatını gördüklerinde zihinlerinde yer alan ve daha önceki alışverişlerde ödedikleri fiyatları göz önünde bulundurarak o ürüne ait fiyatın uygunluğunu ölçerler. Eğer bir ürüne indirim yapılmış ise o ürünün önceki fiyatı zihinde çağrılır ve indirim oranının doğru olup olmadığı sorgulanır. Bir ürünün etiketinde yer alan fiyat üzerinden indirim yapılarak satılırken indirimli yeni fiyatın, eski fiyatın sağında veya altında yer aldığında tüketicinin satın alma niyetini etkilediği sonucuna varılmıştır (Yip, 2002). Bunun nedeninin ise tüketicilerin yapılan indirimi bir çıkarma işlemi olarak görmeleri ve eski fiyattan yeni fiyatı çlkarma istekleri olduğu düşünülmektedir. Çalışmada bu sonucu değerlendirerek ilgili uyarana yapılan indirim sonucunda oluşan yeni fiyat eski fiyatın altında yer almaktadır. Böylece anket cevaplayıcılarının çıkarma işlemini daha kolay yapmaları istenmiştir. İkinci olarak bir ürüne yapılacak olan indirim miktarının tüketicilerin üzerindeki etkileri incelendiğinde ürüne \%10 oranında yaplan indirimin düşük indirim olarak kabul gördügü (Grewal vd.,1996) \%30 oranında yapılan bir indirimin ise değerlendirmeyi arttıran büyük indirim olarak algılandığı sonucuna varılmıștır (Lichtenstein vd., 1991). Bu değerlendirmeler sonucunda araştırmada yer alan uyarana yapılan indirim miktarı \%30 olarak seçilmiştir.

Araştırmada kullanılan bir başka uyaran olan ürünün indirimli fiyat renginin kırmızı olarak seçilmesinin nedeni ile ilgili olarak Puccinelli vd. (2013)'nin çalışmasından yararlanılmıştır. Puccinelli vd. (2013)'nin yapmış olduğu çalışmada, renklerin fiyat algısı üzerindeki etkisi üzerinde durulmuştur. Araştırmada, kırmızı rengin tüketicilerin tasarruf algıları 
üzerindeki etkisini değerlendiren dört çalışmanın bulguları rapor edilmektedir. Sonuç olarak kırmızı rengin tüketicilerin satın alma niyetlerini daha fazla etkilediği ve fiyat hatırlaması sağladığı çalışmadan çıkarılan sonuç olarak karşımıza çıkmaktadır.

Araştırmada tüketicilerin fiyat algısını ölçmek amacıyla Lien vd. (2015)'in, satın alma niyetini ölçmek amaciyla Dodds vd. (1991)'nin, çevrimiçi yorumlara yönelik genel tutum ve yorum sayısını ölçmek için Park ve Lee (2008)'in ve algılanan inanılırlığı ölçmek üzere Urbany vd. (1988)'nin çalışmalarında kullandıkları ölçeklerden yararlanılmıştır. Kovaryans değişken olarak değerlendirilen ilgilenim düzeyini ölçmek için Zaichkowsky (1985)'nin geliștirdiği, Celuch ve Taylor (1999) tarafından sekiz değişkene indirgenmiş olan ölçek, önceki satın alma deneyimini ölçmek için Thamizhvanan ve Xavier (2013)'in geliştirdiği ölçek kullanılmıştır.

\section{ANAKÜTLE VE ÖRNEKLEM}

Araştırmanın anakütlesini Mersin Üniversitesinde öğrenim görmekte olan ön lisans, lisans, yüksek lisans ve doktora öğrencileri oluşturmaktadır. Araştırmada belirtilen anakütlenin hepsinden veri elde etmenin hem ekonomik hem de zaman maliyeti yüksek olması nedeniyle örneklem seçme durumunda kalınmıştır. Bu nedenle olasılıklı olmayan örnekleme türlerinden biri olan kota örneklemesi yöntemi seçilmiştir. Kota örneklemesinin seçilme nedeni olarak, inceleme ve araştırma konusu olan topluluğun belli özelliklerini yansitabilmek için, topluluğun içinden yalnız belli özelliklerde olan örneklerin (yaş, cinsiyet, eğitim durumu vb.) alınmasını gerektiren araştırma yöntemi olması, homojen veriler elde edebilmek üzere uygun bir yapıya sahip olması ve zaman kısıtlılığı gibi nedenler gösterilebilmektedir. Bir araştırmada kullanılacak olan örneklemin büyüklügünün yapılacak olan analizde yeterli olabilmesi için en az 300 örneklem sayısının uygun olduğu belirtilmektedir (Tabachnick ve Fidel, 2007). Floyd ve Widaman (1995) ise 300400 civarında bir örneklem büyüklügünün yeterli olduğundan bahsetmektedir. Bu bilgiler doğrultusunda bu çalışmada incelenen 8 grup bulunduğundan her bir grup için 50 kişi seçilmiş ve toplamda 400 kişiden oluşan örneklem üzerinde araştırma gerçekleștirilmiştir.

\section{UYGULAMA}

Büyük gruplara uygulanacak anketlerin anlaşılırlığı ve genel olarak uygulama tarzını değerlendirmek üzere, küçük bir grup üzerinde uygulama (pilot uygulama) yapılmasının yararlı olacağı düşünülmektedir (Büyüköztürk vd., 2007: 135). Bu amaçla, anket formunun oluşturulmasının ardından anketlerde bulunan ifadeleri test etmek için 01-08 Mayıs 2018 tarihleri arasında Mersin Üniversitesi Fen Edebiyat Fakültesi öğrencileri ile pilot çalışma yapılmış ve çalışma sonucunda elde edilen veriler neticesinde ankette yer alan ve düzeltilmesi uygun görülen bazı ifadeler düzeltilerek anket uygulamaya hazır hale getirilmiştir. Bu doğrultuda 2018 yılının MayısEkim ayları içerisinde uygulanan anketlerden araştırmanın verileri elde edilmiştir. Çalışmada kullanılan anketler araştırmacı tarafından cevaplayıcılar ile yüz yüze görüşmeler aracılığı ile uygulanmıştır.

\section{BULGULAR}

Araştırmaya katılan tüketicilerin cinsiyet, gelir, yaş, eğitim gördüğü alan ve eğitim durumlarına ait demografik özelliklerini içeren bilgiler Tablo 1'de gösterilmektedir.

Tablo 1'de görüldüğü üzere araştırmaya katılanların verdiği cevaplara göre katılımcıların yaklaşık \%45'inin erkek ve \%55'inin kadın olduğu, çoğunluğunun (\%63) gelir düzeyinin 1000 TL ve altında olduğu, çoğunun (\%80) lisans öğrenimi görmekte olduğu ve ağırlıklı olarak (\%63) sosyal ve fen alanlarında eğitim gördükleri gözlemlenmektedir. Araştırmaya katılanların yaşları 18 ile 56 arasında değişmekte olup çoğunlukla (\%68) 18-22 yaş aralığında oldukları gözlemlenmektedir. 
Tablo 1: Katılımcıların Demografik Özellikleri.

\begin{tabular}{|c|c|c|c|}
\hline Değişken Adı & Kategoriler & Frekans (n) & Yüzde (\%) \\
\hline \multirow{2}{*}{ Cinsiyet } & Kadın & 180 & 45.0 \\
\hline & Erkek & 220 & 55.0 \\
\hline Gelir & $\begin{array}{l}1000 \text { TL ve altı } \\
1001-1500 \mathrm{TL} \\
1501-2000 \mathrm{TL} \\
2001-2500 \mathrm{TL} \\
2501 \text { TL ve üzeri }\end{array}$ & $\begin{array}{c}252 \\
64 \\
44 \\
12 \\
28\end{array}$ & $\begin{array}{c}63.0 \\
16.0 \\
11.0 \\
3.0 \\
7.0\end{array}$ \\
\hline \multirow{5}{*}{ Yaş } & $18-22$ & 274 & 68.5 \\
\hline & $23-27$ & 94 & 23.5 \\
\hline & $28-33$ & 17 & 4.3 \\
\hline & $34-41$ & 8 & 2.0 \\
\hline & 42 ve üzeri & 7 & 1.7 \\
\hline Alan & \begin{tabular}{|l|} 
Sosyal \\
Fen \\
Mühendislik \\
Sağlık
\end{tabular} & $\begin{array}{c}125 \\
126 \\
100 \\
49\end{array}$ & $\begin{array}{l}31.3 \\
31.4 \\
25.0 \\
12.3\end{array}$ \\
\hline \multirow{4}{*}{$\begin{array}{l}\text { Ĕgitim } \\
\text { Durumu }\end{array}$} & Ön Lisans & 53 & 13.3 \\
\hline & Lisans & 318 & 79.4 \\
\hline & Yüksek Lisans & 23 & 5.8 \\
\hline & Doktora & 6 & 1.5 \\
\hline
\end{tabular}

\subsection{Faktör analizi}

Faktör analizi, birbirleri ile ilişkili olan birçok değişkenin bir araya getirilip anlamlı değişkenler ortaya çıkarmayı amaç edinen çok değișkenli bir istatistik olarak tanımlanmaktadır (Büyüköztürk, 2007: 133). Faktör analizi yaparken örneklem sayısının en az 300 olması gerektiği ifade edilmekte olup örneklem büyüklügünün yapılacak olan analize uygun olup olmadığını belirlemek için KaiserMeyer-Olkin (KMO) testinin kullanılması ve KMO değerinin 0,5'in üzerinde olması gerekmektedir (Çokluk vd., 2016: 206). Verilerin faktör analizine uygun olduğu, ayrıca örneklem sayısının faktör analizi için yeterliliğini test eden Kaiser-Meyer-Olkin değerine bakılmış ve örneklem yeterlilik ölçütü değerinin $(\mathrm{KMO}=0,843 ; \mathrm{p}=0,000<0,005)$ alınan örneklemin faktör analizinin uygulanabilmesi için yeterli olduğu belirlenmiştir.

Faktör analizinde olan çok değişkenli normalliğin Bartlett Küresellik testi ile değerlendirilmesi gerektiği (Çokluk vd., 2016: 208) ve bununla birlikte ki-kare istatistik test değerine bakılması gerektiği ve çıkan bu değerin 0.05 'ten küçük olması gerektiği belirtilmektedir. Çalışmada hesaplanan Bartlett'in Küresellik testi sonucunda elde edilen Ki-kare değeri $(\chi 2=5877,494 ; p=0,000)$ gerçekleştirilen faktör analizinin uygun olduğunu göstermektedir.

Ortak varyans, bir değișkenin analizdeki diğer değișkenlerle paylaştığı varyans miktarına denir (Karagöz ve Kösterelioğlu, 2008: 90). Faktör analizinde değişkenlerde yer alan ifadelerin ortak varyans (communality) değerleri 0,5 'ten düşük olmaması gerekmektedir (Hair vd., 1998). Bu çalışmada, yapılan ilk Faktör analizi sonucunda ortak faktör varyans (communalities) değerinin 0,5 'ten küçük olduğu görülen $(0,430)$ çevrimiçi yorumlara yönelik genel tutum ölçeğinin bir maddesinin aynı zamanda ölçek güvenilirliğini azalttığı görülmüş ve ilgili madde araștırma kapsamından çıkarılmıştır. Geriye kalan toplam ölçek ifadelerine Temel Bileşenler Analizi ve Varimax döndürme yöntemiyle yapılan ikinci faktör analizi sonucunda, ortak varyans (communality) değerlerinin 0,5 ten büyük olduğu ve tüm maddelerin 0,603 ve üzerindeki faktör yüklerine sahip olduğu saptanmıştır. Araștırmanın faktör analiz sonuçları Tablo 2'de verilmiştir.

Pazarlama alanında yapılan araştırmalarda çoklu ölçeklere ait içsel tutarlılığın ölçülmesi ve güvenilirliği test etmek üzere kullanılan en yaygın yöntemlerden biri Cronbach alfa katsayısıdır (Smith ve Albaum, 2005: 366). Bu bilgi doğrultusunda çalışmada kullanılan ölçeklerin güvenilirlik analizleri Cronbach Alfa kullanılarak gerçekleştirilmiştir.

Nunnally (1978)'ye göre araştırmada kullanılan bir ölçeğin güvenilir olup olmadığını söyleyebilmek için Cronbach Alfa katsayısının en az 0,7 olması gerekmektedir. Analiz sonucunda tüm faktörler için Cronbach Alfa değerleri sırasıyla; önceki çevrimiçi satın alma deneyimi ölçeği (ÖSAD) için: 0,861, satın alma niyeti ölçeği için: 0,843 , fiyat ölçeği için: 0,864 , çevrimiçi yorumlara yönelik genel tutum ölçeği için: 0,835, yorum sayısı ölçeği için: 0,763 algılanan inanırlık ölçeği için: 0,554, ilgilenim ölçeği için: 0,950 olduğu ve bu sonuçlara göre ölçeklerin genel olarak güvenilir olduğu gözlenmiştir. 
İzmir İktisat Dergisi / İzmir Journal of Economics, YIL, Cilt(Sayı), ss. X-X

Tablo 2: Araştırmanın Faktör Analizi Sonuçları

\begin{tabular}{|c|c|c|c|c|c|c|c|c|c|}
\hline$*$ & Değişkenler & $\begin{array}{c}\text { Faktör } \\
1\end{array}$ & $\begin{array}{l}\text { Faktör } \\
\quad 2\end{array}$ & $\begin{array}{c}\text { Faktör } \\
3\end{array}$ & $\begin{array}{c}\text { Faktör } \\
4\end{array}$ & $\begin{array}{l}\text { Faktör } \\
5\end{array}$ & $\begin{array}{l}\text { Faktör } \\
\quad 6\end{array}$ & $\begin{array}{l}\text { Faktör } \\
7\end{array}$ & $\begin{array}{l}\text { Cronbach } \\
\text { alfa }\end{array}$ \\
\hline \multirow{5}{*}{ íL } & İL 4 & ,925 & & & & & & & \multirow[t]{5}{*}{,950 } \\
\hline & İL 3 & ,908 & & & & & & & \\
\hline & İL 1 & 905 & & & & & & & \\
\hline & İL 2 & 895 & & & & & & & \\
\hline & İL 5 & 845 & & & & & & & \\
\hline \multirow{4}{*}{$\mathbf{F}$} & F 3 & & 860 & & & & & & \multirow[t]{4}{*}{,864 } \\
\hline & F 2 & & 842 & & & & & & \\
\hline & F 1 & & ,755 & & & & & & \\
\hline & F 4 & & ,748 & & & & & & \\
\hline \multirow{5}{*}{ SAN } & SAN 4 & & & 842 & & & & & \multirow[t]{5}{*}{843} \\
\hline & SAN 1 & & & 781 & & & & & \\
\hline & SAN 5 & & & ,767 & & & & & \\
\hline & SAN 3 & & & 647 & & & & & \\
\hline & SAN 2 & & & ,603 & & & & & \\
\hline \multirow{3}{*}{ ÖSAD } & ÖSAD 2 & & & & ,903 & & & & \multirow[t]{3}{*}{861} \\
\hline & ÖSAD 3 & & & & 872 & & & & \\
\hline & ÖSAD 1 & & & & ,796 & & & & \\
\hline \multirow{3}{*}{ ÇYYGT } & ÇYYGT 2 & & & & & 882 & & & \multirow[t]{3}{*}{835} \\
\hline & ÇYYGT 1 & & & & & 860 & & & \\
\hline & ÇYYGT 4 & & & & & ,716 & & & \\
\hline \multirow{2}{*}{ YS } & YS 2 & & & & & & ,865 & & \multirow[t]{2}{*}{,763 } \\
\hline & YS 1 & & & & & & 830 & & \\
\hline \multirow{2}{*}{ ALGI } & ALGI 1 & & & & & & & 822 & \multirow[t]{2}{*}{,554 } \\
\hline & ALGI 2 & & & & & & & 804 & \\
\hline Özdeğerler & & 6,277 & 3,914 & 2,407 & 1,565 & 1,360 & 1,356 & 1,236 & \\
\hline $\begin{array}{l}\text { Faktörlerin } \\
\text { Açıklayıcılığı }\end{array}$ & & 17,876 & 12,752 & 12,261 & 9,908 & 9,536 & 7,083 & 6,056 & \\
\hline \multicolumn{9}{|c|}{ Kaiser-Meyer-Olkin (KMO) Örneklem Yeterlilik Ölçüsü=0,843 } & \\
\hline \multicolumn{9}{|c|}{ Bartlett Küresellik Testi: Ki-kare değeri=5877,494 Serbestlik derecesi=276 $p=0,000$} & \\
\hline \multicolumn{9}{|c|}{$\begin{array}{l}\text { *il=Illgilenim, F= Fiyat, SAN= Satın alma Niyeti, ÖSAD= Önceki Satın alma Deneyimi, } \\
\text { ÇYYGT= Çevrimiçi Yorumlara Yönelik Genel Tutum, YS= Yorum Sayısı, ALGI=Algılanan İnanırlık }\end{array}$} & \\
\hline
\end{tabular}

\subsection{Hipotez testleri}

$\mathrm{Bu}$ çalışmada iki grup ürün (deneyimsel ve araştırma), iki grup çevrimiçi yorum (az ve çok), iki grup referans fiyattan (var ve yok) oluşan sekiz farklı grup arasındaki farklılıkları test etmek amacıyla, ilgilenim ve önceki satın alma deneyimi değişkenlerinin kovaryans olarak ele alındığı $(2 \times 2 \times 2)$ MANCOVA yöntemi kullanılmıştır. MANCOVA birden fazla grup içerisinde birden fazla bağımlı değişkenin farklılık gösterip göstermediğini araștırmak ve etkisini kontrol etmek üzere kullanılmaktadır (Tabachnick ve Fidell, 2007). Araştırmada incelenen sekiz grubun hangileri olduğuna dair açıklama Tablo 3'te verilmiştir.
Tablo 3:Grup Adlarının Numaralandırılması

\begin{tabular}{|c|l|l|}
\hline $\begin{array}{l}\text { Grup } \\
\text { No }\end{array}$ & Grup ile İlgili Açıklama & $\boldsymbol{n}$ \\
\hline $\mathbf{1}$ & Deneyimsel_referans_fiyatlı_az_yorum & 50 \\
\hline $\mathbf{2}$ & Deneyimsel_referans_fiyatsız_çok_yorum & 50 \\
\hline $\mathbf{3}$ & Deneyimsel_referans_fiyatlı_çok_yorum & 50 \\
\hline $\mathbf{4}$ & Deneyimsel_referans_fiyatsız_çok_yorum & 50 \\
\hline $\mathbf{5}$ & Araştırma_referans_fiyatlı_az_yorum & 50 \\
\hline $\mathbf{6}$ & Araştırma_referans_fiyatsız_az_yorum & 50 \\
\hline $\mathbf{7}$ & Araştırma_referans_fiyatlı_çok_yorum & 50 \\
\hline $\mathbf{8}$ & Araştırma_referans_fiyatsız_çok_yorum & 50 \\
\hline
\end{tabular}

MANCOVA'nın gerçekleştirilebilmesi için, normallik ve varyans-kovaryans matrisinin 
homojenliği gibi varsayımların sağlanması gerekmektedir (Tabachnick ve Fidell, 2007: 303). Analizin gerçekleștirilebilmesi için, kullanılan değişkenlerin çoklu normal dağılıma sahip olmaları, tüm gruplar için kovaryans matrislerinin eşit olması ve bağımsız değişkenler arasında çoklu doğrusal bağlantı probleminin bulunmaması gerekmektedir (Huberty ve Olejnik, 2006).

Varyansların homojenliği Levene's Testi ile Kovaryans matrislerinin eşitliği ise Box's M testi ile incelenmektedir (Kumandaş ve Kutlu, 2011). Kullanılan örneklem sayısının yüksek olduğu çalışmalarda Box's M testi anlamlı çlkabilmektedir (Tabachnick ve Fidell, 2007). Bağımlı değişkenler arasında kovaryans matrislerinin eşitliği için kullanılan Box's M testi sonuçlarına göre araştırmada kovaryans eşitliği şartı sağlandığı görülmektedir (Box's $\mathrm{M}=135.061, \mathrm{p}=0,053>$.05).

Levene test bağımsız iki örneğin varyanslarının eşitliğini normal dağılım varsayımı kullanmadan test eden bir yöntemdir (Mırtağığlu, vd., 2017). Levene testinde homojenliğin sağlanması için yapılan test sonuçlarında çlkan değerin 0.05 'ten büyük olması gerekmektedir. Çalışmada yer alan gruplar üzerinden eşitliği test edilen hata varyanslarının bağımlı değişkenlerine ait Tablo 4'te de görülen Levene Testi sonuçlarına göre varyans eşitliği $(p>0,05)$ şartı sağlanmıştır.

Tablo 4: Araștırmada Yer Alan Varyansların Eşitliği (Levene) Test Sonuçları

\begin{tabular}{|c|c|c|c|c|}
\hline \multicolumn{1}{c|}{} & $\mathrm{F}$ & $\mathrm{sd} 1$ & $\mathrm{sd} 2$ & Anlamlılık \\
\hline Fiyat Algısı & 1,687 & 7 & 392 & 0,111 \\
\hline $\begin{array}{c}\text { Satın Alma } \\
\text { Niyeti }\end{array}$ & 1,126 & 7 & 392 & 0,345 \\
\hline $\begin{array}{c}\text { Çevrimiçi } \\
\text { Yorumlara } \\
\text { Yönelik Genel } \\
\text { Tutum }\end{array}$ & 0,857 & 7 & 392 & 0,541 \\
\hline Yorum Sayısı & 1,688 & 7 & 392 & 0,110 \\
\hline $\begin{array}{c}\text { Algılanan } \\
\text { İnanılırlık }\end{array}$ & 1,586 & 7 & 392 & 0,138 \\
\hline
\end{tabular}

Ayrıca araștırmada kullanılan örneklem sayısının her grupta eşit ve yeterli sayıda $(n>30)$ olması durumunda varyansların homojenliği ve varyans-kovaryans matrisinin homojenliğinin şartlarının sağlandığı varsayllmakta (Tabachnick ve Fidell, 2007; Pallant, 2005), yeterince büyük $(n>200)$ örneklemin olması halinde, normallik varsayımının sağlandı $\breve{g}$ belirtilmektedir (Tabachnick ve Fidell, 2007). Bu çalışmada da örneklem sayısının normallik varsayımını sağlayacak büyüklükte $(n=400>200)$ ve her bir grubun 50'şer katılımcıdan oluşması nedeniyle, MANCOVA analizinin gerçekleştirilmesi için gerekli varsayımların sağlandığı desteklenmektedir.

Tablo 5: Çok Değișkenli Testler

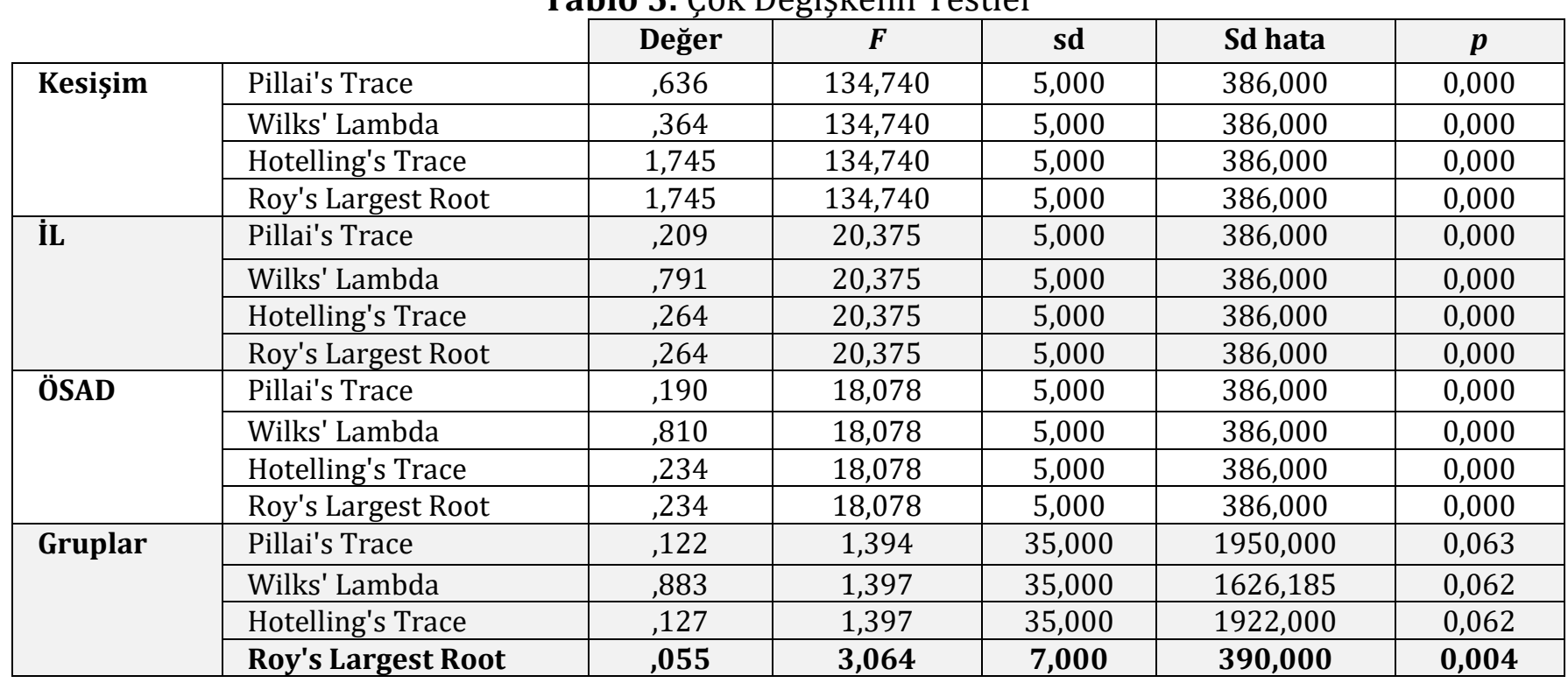


Çalışmada yapılan çok değişkenli testler Tablo 5'da gösterilmektedir. Özdeğerler, her bir özvektör tarafından açıklanan varyasyon miktarını gösterir. MANOVA'da, Wilks' Lambda, Pillai's Trace ve Hotelling-Lawley trace, tüm öz değerlerin toplamına dayanır. Fakat Roy's Largest Root testi ise ilk öz değerdir (Scheiner, 2001: 105). MANCOVA sonuçlarına göre, araştırmada incelenen gruplar arasında farklılıkların anlamlı olduğu (Roy's Largest Root testine göre $F=3.064 ; p=0,004$ düzeyinde) sonucuna ulaşılmıştır. MANCOVA'da post-hoc testlere izin vermesi ve güçlü test istatistiklerini sağlaması nedeniyle (Scheiner, 2001) Roy'un en büyük kökü testi dikkate alınmıştır.

Çalışmada yapılan grup içi etki testleri Tablo 6'da gösterilmektedir. Grup içi Etki Testleri, gruplar arası farklılıklarin bulunup bulunmadığını test etmekte olup, bu çalışmada incelenen gruplar arasında, satın alma niyeti ve yorum sayısı bağlamlarında farklılıkların bulunduğu sonucuna ulaşılmıştır (satın alma niyeti için $p=0,019$; yorum sayısı için $p=0,016$ ). Dolayısıyla araştırmada incelenen sekiz grup arasından en az biri satın alma niyeti bağlamında farklılık gösterdiğine yönelik H1 ile, araștırmada incelenen sekiz grup arasından en az birinin çevrimiçi yorum sayısı bağlamında farklılık gösterdiğine dair $\mathrm{H} 4$ hipotezleri desteklenmiş olup, H2, H3 ve H5 hipotezleri desteklenememiştir.

Çoklu karşılaştırma testleri Tablo 7'den incelendiğinde satın alma niyeti ve yorum sayısı arasında araştırma ve deneyimsel ürünler kapsamında anlamlı farklılıklar bulunduğu gözlemlenmektedir. $\mathrm{Bu}$ anlaml farklılıklar sırasıyla açıklanacak olursa, referans fiyatı bulunan ve az yorum yapılmış olan deneyimsel ürünler ile referans fiyatı bulunan az yorum yapılmış olan araştırma ürünlerinin satın alma niyetleri bağlamında anlamlı farklılık gösterdiği sonucu elde edilmiştir $(p=0,039)$.

Referans fiyatlı ve az yorum yapılmış deneyimsel bir ürün ile referans fiyatı bulunmayan çok yorum yapılmış araștırma ürünü arasında satın alma niyetleri bağlamında anlamlı farklılıklar olduğu sonucuna ulaşılmıştır $\quad(p=0,016)$. Referans fiyatı bulunmayan çok yorum yapılmış deneyim ürünü ile referans fiyatı bulunan az yorum yapılmış olan araștırma ürünlerinin satın alma niyetleri bağlamında anlamlı farklılık gösterdiği sonucuna ulaşılmıştır $(p=0,007)$. Referans fiyatı bulunmayan çok yorum yapılmış deneyim ürünü ile referans fiyatı bulunmayan çok yorum yapılmış araştırma ürünlerinin satın alma niyetleri bağlamında anlamlı farklılık gösterdiği sonucu elde edilmiştir $(p=0,002)$. Referans fiyatı bulunan ve çok yorum yapılmış olan deneyimsel ürünler ile referans fiyatı bulunan az yorum yapılmış olan araştırma ürünlerinin satın alma niyetleri bağlamında anlamlı farklılı gösterdiği sonucuna ulaşılmaktadır $(p=0,018)$.

Referans fiyatı bulunan ve çok yorum yapılmış olan deneyimsel ürünler ile referans fiyatı bulunmayan çok yorum yapılmış araştırma ürünlerinin satın alma niyetleri bağlamında anlamlı farklılık gösterdiği bulunmuştur $(p=0,007)$. Referans fiyatı bulunmayan çok yorum yapılmış deneyim ürünü ile referans fiyatı bulunmayan çok yorum yapılmış araştırma ürünlerinin satın alma niyetleri bağlamında anlamlı farklılı gösterdiği sonucuna ulaşılmıștır ( $p=0,035)$.

Referans fiyatı bulunmayan az yorum yapılmış olan araștırma ürünü ile referans fiyatı bulunmayan çok yorum yapılmış araştırma ürünlerinin satın alma niyetleri bağlamında anlamlı farklılık gösterdiği sonucu elde edilmiştir $(p=0,026)$. Referans fiyatı bulunan çok yorum yapılmış olan araştırma ürünü ile referans fiyatı bulunmayan çok yorum yapılmış araștırma ürünlerinin satın alma niyetleri bağlamında anlamlı farklılı gösterdiği bulunmuştur $(p=0,031)$. Referans fiyatı bulunan ve çok yorum yapılmış olan deneyimsel ürünler ile referans fiyatı bulunmayan çok yorum yapılmış olan deneyimsel ürünlerinin satın alma niyetleri bağlamında anlamlı farklılık gösterdiği sonucuna ulaşılmıştır $(p=0,040)$. Referans 
fiyatı bulunmayan çok yorum yapılmış deneyim ürünü ile referans fiyatı bulunmayan çok yorum yapılmış olan deneyimsel ürünlerinin satın alma niyetleri bağlamında anlamlı farkllılı gösterdiği sonucu elde edilmiştir $(p=0,000)$. Referans fiyatı bulunmayan çok yorum yapılmış deneyim ürünü ile referans fiyatı bulunan az yorum yapılmış olan araștırma ürünlerinin satın alma niyetleri bağlamında anlamlı farklılık gösterdiği sonucu elde edilmiştir $(p=0,002)$. Referans fiyatı bulunan çok yorum yapılmış olan araştırma ürünü ile referans fiyatı bulunmayan çok yorum yapılmış olan deneyimsel ürünlerinin satın alma niyetleri bağlamında anlamlı farklılık gösterdiği sonucu elde edilmiştir $(\mathrm{p}=0,021)$.

Tablo 6:Grup İçi Etki Testleri

\begin{tabular}{|c|c|c|c|c|c|c|}
\hline Kaynak & $\begin{array}{c}\text { Bağımlı } \\
\text { Değișken }\end{array}$ & $\begin{array}{c}\text { Tip III Kareler } \\
\text { Toplamı }\end{array}$ & sd & $\begin{array}{l}\text { Ortalama } \\
\text { Kare }\end{array}$ & $\boldsymbol{F}$ & $p$ \\
\hline \multirow{5}{*}{ Düzeltilmiş Model } & $\mathrm{F}$ & 113,352 & 9 & 12,595 & 6,618 &, 000 \\
\hline & SAN & 186,699 & 9 & 20,744 & 12,170 &, 000 \\
\hline & ÇYYGT & 176,155 & 9 & 19,573 & 7,581 & 000 \\
\hline & YS & 122,722 & 9 & 13,636 & 5,411 & ,000 \\
\hline & ALGI & 27,849 & 9 & 3,094 & 1,037 & ,410 \\
\hline \multirow{5}{*}{ Kesişim } & $\mathrm{F}$ & 320,311 & 1 & 320,311 & 168,311 &, 000 \\
\hline & SAN & 517,163 & 1 & 517,163 & 303,390 & 000 \\
\hline & ÇYYGT & 501,080 & 1 & 501,080 & 194,090 &, 000 \\
\hline & YS & 375,324 & 1 & 375,324 & 148,942 &, 000 \\
\hline & ALGI & 639,323 & 1 & 639,323 & 214,192 & 000 \\
\hline \multirow{5}{*}{ İL } & $\mathrm{F}$ & 10,598 & 1 & 10,598 & 5,569 & 019 \\
\hline & SAN & 152,428 & 1 & 152,428 & 89,421 &, 000 \\
\hline & ÇYYGT & 18,481 & 1 & 18,481 & 7,159 & 008 \\
\hline & YS & 15,782 & 1 & 15,782 & 6,263 & ,013 \\
\hline & ALGI & 922 & 1 & ,922 & 309 & ,579 \\
\hline \multirow{5}{*}{ ÖSAD } & $\mathrm{F}$ & 91,084 & 1 & 91,084 & 47,861 &, 000 \\
\hline & SAN & 11,520 & 1 & 11,520 & 6,758 & 010 \\
\hline & ÇYYGT & 148,597 & 1 & 148,597 & 57,558 & 000 \\
\hline & YS & 63,852 & 1 & 63,852 & 25,339 &, 000 \\
\hline & ALGI & 1,665 & 1 & 1,665 & ,558 & ,456 \\
\hline \multirow{5}{*}{ Grup No } & $\mathrm{F}$ & 11,132 & 7 & 1,590 & 836 & ,558 \\
\hline & SAN & 29,070 & 7 & 4,153 & 2,436 & ,019 \\
\hline & ÇYYGT & 7,410 & 7 & 1,059 & 410 & 896 \\
\hline & YS & 44,106 & 7 & 6,301 & 2,500 & ,016 \\
\hline & ALGI & 24,133 & 7 & 3,448 & 1,155 & ,328 \\
\hline \multirow{5}{*}{ Hata } & $\mathrm{F}$ & 742,204 & 390 & 1,903 & & \\
\hline & SAN & 664,799 & 390 & 1,705 & & \\
\hline & ÇYYGT & 1006,857 & 390 & 2,582 & & \\
\hline & YS & 982,772 & 390 & 2,520 & & \\
\hline & ALGI & 1164,075 & 390 & 2,985 & & \\
\hline \multirow{5}{*}{ Toplam } & $\mathrm{F}$ & 6535,063 & 400 & & & \\
\hline & SAN & 4326,600 & 400 & & & \\
\hline & ÇYYGT & 10100,667 & 400 & & & \\
\hline & YS & 6741,750 & 400 & & & \\
\hline & ALGI & 7838,250 & 400 & & & \\
\hline \multirow{5}{*}{ Düzeltilen Toplam } & $\mathrm{F}$ & 855,556 & 399 & & & \\
\hline & SAN & 851,498 & 399 & & & \\
\hline & ÇYYGT & 1183,012 & 399 & & & \\
\hline & YS & 1105,494 & 399 & & & \\
\hline & ALGI & 1191,924 & 399 & & & \\
\hline
\end{tabular}


Tablo 7: Çoklu Karşılaștırma Testleri

\begin{tabular}{|c|c|c|c|c|c|}
\hline Değişken & Grup (I) & Grup (J) & Ortalamalar Farkı (I-J) & Standart Hata & $p$ \\
\hline \multirow{9}{*}{ Satın Alma Niyeti } & \multirow{2}{*}{1} & 5 & ,540 & 261 & 039 \\
\hline & & 8 & 632 & 261 & 016 \\
\hline & \multirow{2}{*}{2} & 5 &, 716 & ,263 &, 007 \\
\hline & & 8 & ,809 & 263 & ,002 \\
\hline & \multirow{2}{*}{3} & 5 & 625 & ,263 & ,018 \\
\hline & & 8 &, $717^{*}$ & 263 & 007 \\
\hline & 4 & 8 & ,557 & ,263 &, 035 \\
\hline & 6 & 8 &, 582 & ,261 &, 026 \\
\hline & 7 & 8 &, 566 &, 261 & , 031 \\
\hline \multirow{4}{*}{ Yorum Sayısı } & 3 & 2 & 654 & ,318 & 040 \\
\hline & \multirow{2}{*}{4} & 2 & 1,147 & 318 & ,000 \\
\hline & & 5 & 1,015 & ,320 & ,002 \\
\hline & 7 & 2 & 744 & 320 & 021 \\
\hline
\end{tabular}

\section{SONUÇ VE ÖNERILER}

$\mathrm{Bu}$ araştırmanın sonucunda tüketicilerin yapacakları alışverişlerde özellikle yorum sayısını dikkate aldıkları ve buna göre satın alma niyetlerinin etkilendiği gözlemlenmiştir. Bir ürün için yapılan yorumlar, o ürünle ilgili olarak tüketicilere bilgilendirme mesajları vermekte olup, bu çalışmaya katılan tüketiciler bağlamında araştırmanın sonuçları değerlendirildiğinde, yorum sayısının tüketicilerin satın alma niyetlerine etkisinin olduğu ortaya çıkmıştır. Bu açıdan işletmelerin bir iletişim ve tutundurma aracı olarak ürünlere yapılan tüketici yorumlarını dikkatlice inceleyip değerlendirmeler yapması ve yönetmesi gerekliliği ortaya çıkmaktadır. Bu bağlamda işletmelerin, tüketicilerin yaptıkları ürün yorumlarına müdahale etmemesi ve yorumların sadece ürün deneyimi yaşamış olan tüketiciler tarafından oluşturulmasına izin vermesi önerilebilir. Dolayısıyla ürünü satın alacak tüketiciler tarafından, ürünlere yapılan yorumların tüketicinin gözünde gerçekçiliğini artıracak ve satın alma niyetini bu bağlamda gerçekleștirmeleri sağlanacaktır.

Araştırmacılara çalışmanın kapsamının geliştirilmesi adına yorum sayısının satın alma niyetine etkisinin yanı sıra yapılan yorumların olumlu ve olumsuz yorumlar olmak üzere ele alınarak satın alma niyetine etkisinin incelenmesi önerilebilir. Böylece bu alandaki literatüre katkı sağlanabilecektir.
$\mathrm{Bu}$ çalışmada, satın alınacak bir üründe referans fiyatlı etiketin bulunup bulunmaması, araştırmada incelenen değişkenler bakımından anlamlı farklılıklar göstermediği sonucuna ulaşılmıştır. $\mathrm{Bu}$ da tüketicilerin satın alma niyetlerini etkileyen unsurların başında fiyattan daha önce, ürüne yapılan yorumların sayısının geldiğini göstermekte ve bu durum çevrimiçi yorumların gücünü de ortaya koymaktadır.

Pazarlama karması, pazarlama yöneticilerinin faaliyetlerini yürütmesinde kolaylık sağlayan ve işletmelerin rekabetçi konumlarında önemli etkileri olan bir kavramdır. Bu çalışma ile pazarlama karmasının içe odaklı yapısını bertaraf edecek tüketici davranışlarını kapsayan dışsal unsurların dâhil edildiği düşünülmektedir. Özellikle ürün gruplarının, çevrimiçi yorum ile tutundurmanın ve referans fiyat ile fiyatın bir arada eşgüdüm içerisinde yer aldığı bu çalışmanın pazarlama yazınına olduğu kadar işletme yöneticilerine de katkılar sağlayacağı düşünülmektedir.

$\mathrm{Bu}$ çalışmada kullanılan araştırma ve deneyimsel özelliğe sahip olan ürünler, bu alanda geçmişte yapılan çalışmalar dikkate alınarak seçilmiştir. Ancak günümüz koşulları, gelişen bilgi teknolojileri ve internetin yaygın bir şekilde kullanılması nedeniyle bazı ürünlerin araştırma ürünü ve deneyimsel ürün özelliklerinin farklılaştığı ve her iki ürün kategorisine de girebilecek ürünlerin olduğu söylenebilir. Örnek ve öneri olarak giyim 
ürünleri geçmiş yıllardaki çalışmalarda araştırma ürünü kategorisinde yer almaktayken günümüz tüketicilerinin bakış açısı değişmiş ve giyim ürünlerinin artık sadece araştırma ürünü değil aynı zamanda deneyimsel ürün sınıfına girdiği görülür hale gelmiştir.

Araştırma ve deneyimsel ürünlerin ele alınacağı farklı araștırmalar ile ürün sınıflandırmaları tekrar gözden geçirilebilir. Gelecekte gerçekleștirilecek araştırmalarla da farklı ürün tipolojileri (örneğin; hedonikfaydacl, kolayda-beğenmeli-özellikli, vb.) üzerine çalışmalar yapılması ve ürün türlerinin tüketicilerin satın alma niyetlerine etkisinin incelenmesi önerilebilir. Ayrıca bu araştırmada kullanılan araștırma ve deneyimsel ürünlerden daha farklı ürünlerin incelenmesi ve günümüzde bu ürünlerin tüketiciler tarafından nasıl değerlendirildiğinin ölçülmesi önerilebilir.

$\mathrm{Bu}$ çalışmada, zaman ve maliyet kısıtlarının bulunması nedeniyle çalışılabilir bir çalışma evreni seçilmiş ve bu evreni temsil edebilecek bir örneklem üzerinde araştırma gerçekleştirilmiştir. Araştırmada örneklem olarak öğrencilerin seçilmiş olması araştırma sonuçlarının genellenebilmesi için bir kısıt olmaktadır. Bu nedenle, daha sonra yapılacak olan çalışmaların şehir veya bölgeler bazında da gerçekleştirilmesi genellemeye imkan sağlayacaktır.

\section{REFERANSLAR}

Aggarwal, P. ve Vaidyanathan, R. (2005). Perceived effectiveness of recommendation agent routines: search vs. experience goods. International Journal of Internet Marketing and Advertising, 2(1-2), 38-55.

Akhter, S. H. (2009). Niches at the edges: price-value tradeoff, consumer behavior, and marketing strategy. Journal of Product and Brand Management, 18(2), 136-142.

Alba, J., Lynch, J., Weitz, B., Janiszewski, C., Lutz, R., Sawyer, A., ve Wood, S. (1997). Interactive home shopping: consumer, retailer, and manufacturer incentives to participate in electronic marketplaces. The Journal of Marketing, 61(3), 38-53.

Al-Jeraisy, K. I. A. (2008). Consumer Behaviour, 3. Riyadh, Saudi Arabia, 338p. Enstitüsü Dergisi 2014 18(1): 441, 460.

Armstrong, G ve Kotler, P. (2007) Marketing An Introduction, (8 th ed.). New Jersey: Pearson Prentice Hall.

Asch, S. E. (1951). Effects of group pressure upon the modification and distortion of judgments, in: H. Guetzkow (Ed.), Groups,
Leadership and Men, Carnegie Press, Pittsburgh, PA, 177-190.

Aydın, B. O. (2014). Elektronik agizdan agiza iletişim: tüketici motivasyonlarinin analizi. Selçuk Üniversitesi Sosyal Bilimler Enstitüsü Dergisi, (32), 13-25.

Briesch, R. A., Krishnamurthi, L., Mazumdar, T., ve Raj, S.P. (1997). A comparative analysis of reference price models. Journal of Consumer Research, 24(2), 202-214.

Büyüköztürk, Ş. (2007), Sosyal Bilimler için Veri Analizi El Kitabı, Ankara: Pegem Yayıncılık.

Campbell, J.D. ve Fairey, P.J. (1989). Informational and normative routes to conformity: the effect of faction size as a function of norm extremity and attention to the stimulus, Journal of Personality and Social Psychology, 57(3), 457-468.

Celuch, K., ve Taylor, S. (1999). Involvement with services: An empirical replication and extension of Zaichkowsky's personal involvement inventory. Journal of Consumer Satisfaction, Dissatisfaction and Complaining Behavior, 12, 109-122. 
Cemalcılar, İ. (1999). Pazarlama, kavramlar-kararlar. İstanbul: Beta Basım Dağıtım A.Ş.

Chevalier, J. A. ve Mayzlin, D. (2006). The effect of word of mouth on sales: online book reviews. Journal of Marketing Research, 43(3), 345-354.

Cui, G., Lui, H. K., ve Guo, X. (2012). The effect of online consumer reviews on new product sales. International Journal of Electronic Commerce, 17(1), 39-58.

Çokluk, Ö, Şekercioğlu, G. ve Büyüköztürk, Ș. (2016). Sosyal bilimler için çok değişkenli istatistik: SPSS ve LISREL uygulamaları. (1. bs), Ankara: Pegem Akademi.

Daft, R. L., ve Lengel, R. H. (1984). "Information Richness: A New Approach to Manager Information Processing and Organization Design," in Research in Organization Behavior, Vol. 6, Staw, Barry, and Cummings, L.L., eds. Greenwich, CT: JAI Press, 191-233.

Dodds, W. B., Monroe, K. B., ve Grewal, D. (1991). Effects of price, brand, and store information on buyers' product evaluations. Journal of Marketing Research, 28(3), 307-319.

Durmaz, Y., ve Yardimcioğlu, M. (2016). Ürün kararları ve stratejileri üzerine teorik bir yaklaşım. Kahramanmaraş Sütçü İmam Üniversitesi İktisadi ve İdari Bilimler Fakültesi Dergisi, 5(2), 367-387.

Estelami H. ve Maxwell, S. (2003). Perspectives in Behavioral Pricing. Journal of Business Research, 56(2), 401-403.

Floyd, F. J. ve Widaman, K. F. (1995). Factor analysis in the development and refinement of clinical assessment instruments. Psychological Assessment, 7(3), 286-299.

Ford, G. T., Smith, D. B., ve Swasy, J. L. (1990). Consumer skepticism of advertising claims: Testing hypotheses from economics of information. Journal of Consumer Research, 16(4), 433-441.

Franke, G. R., Huhmann, B. A., ve Mothersbaugh, D. L. (2004). Information content and consumer readership of print ads: a comparison of search and experience products. Journal of the Academy of Marketing Science, 32(1), 20-31.

Gabor, A. ve Granger, C. W. J. (1977). Pricing, principles and practices. Heinemann Educational Publishers.

Gijsbrechts, E. (1993). Prices and pricing research in consumer marketing: Some recent developments. International Journal $\mathrm{f}$ Research in Marketing, 10(2), 115-151.

Grewal, D., Marmorstein, H., ve Sharma, A. (1996). Communicating price information through semantic cues: the moderating effects of situation and discount size. Journal of Consumer Research, 23(2), 148-155.

Ha, Y. W. ve Hoch, S. J. (1989). Ambiguity, processing strategy, and advertising-evidence interactions. Journal of Consumer Research, 16(3), 354-360.

Hair, J. F., Anderson, R. E., Tatham, R. L., ve Black, W. C. (1998). Multivariate Data Analysis, New Jersey: Prentice-Hall International.

Hoch, S. J., ve Deighton, J. (1989). Managing what consumers learn from experience. The Journal of Marketing, 1-20.

Hoch, S. J., ve Ha, Y. W. (1986). Consumer learning: Advertising and the ambiguity of product experience. Journal of consumer research, 13(2), 221-233.

Hoffman, D. L., ve Novak, T. P. (1996). Marketing in hypermedia computer-mediated environments: Conceptual foundations. Journal of Marketing, 60(3), 50-68.

Hsieh, Y. C., Chiu, H. C., ve Chiang, M. Y. (2005). Maintaining a committed online customer: A study across search-experiencecredence products. Journal of Retailing, 81(1), 75-82. 
Huang, L., Tan, C. H., Ke, W., ve Wei, K. K. (2013). Comprehension and assessment of product reviews: A review-product congruity proposition. Journal of Management Information Systems, 30(3), 311-343.

Huang, P., Lurie, N. H., ve Mitra, S. (2009). Searching for experience on the web: an empirical examination of consumer behavior for search and experience goods. Journal of Marketing, 73(2), 55-69.

Huberty, C. J., ve Olejnik, S. (2006). Applied MANOVA and discriminant analysis.. Hoboken, NJ: Jone Hiley ve Sons.

Kahneman, D. ve Tversky, A. (2013). Prospect theory: An analysis of decision under risk. In Handbook of the fundamentals of financial decision making: Part I (99-127).

Kalwani, M. U., Yim, C. K., Rinne, H. J., ve Sugita, Y. (1990). A price expectations model of customer brand choice. Journal of Marketing Research, 27(3), 251-262.

Kalyanaram, G. ve Winer, R. S. (1995). Empirical generalizations from reference price research. Marketing science, 14(3_supplement), G161-G169.

Karagöz, Y. ve Kösterelioğlu, İ. (2008). İletişim becerileri değerlendirme ölçeğinin faktör analizi metodu ile geliştirilmesi. Dumlupınar Üniversitesi Sosyal Bilimler Dergisi, (21), 81-97.

Klein, L. R. (1998). Evaluating the potential of interactive media through a new lens: Search versus experience goods. Journal of Business Research, 41(3), 195-203.

Kopalle, P. K. ve Lindsey-Mullikin, J. (2003). The impact of external reference price on consumer price expectations. Journal of Retailing, 79(4), 225-236.

Kumandaş, H., ve Kutlu, Ö. (2011). İlköğretim beşinci sınıf öğrencilerinin performans görevlerine yönelik tutumlarının akademik başarılarına ve dersleri sevme durumlarına göre incelenmesi. Eğitimde ve
Psikolojide Ölçme ve Değerlendirme Dergisi, 2(2).

Kwon, O. ve Sung, Y. (2012). Shifting selves and product reviews: How the effects of product reviews vary depending on the selfviews and self-regulatory goals of consumers. International Journal of Electronic Commerce, 17(1), 59-82.

Lee, J., Lee, J. N., ve Shin, H. (2011). The long tail or the short tail: The category-specific impact of eWOM on sales distribution. Decision Support Systems, 51(3), 466-479.

Lichtenstein, D. R., Burton, S., ve Karson, E. J. (1991). The effect of semantic cues on consumer perceptions of reference price ads. Journal of Consumer Research, 18(3), 380391.

Lien, C. H., Wen, M. J., Huang, L. C., ve Wu, K. L. (2015). Online hotel booking: The effects of brand image, price, trust and value on purchase intentions. Asia Pacific Management Review, 20(4), 210-218.

Lowengart, O. (2002). Reference price conceptualisations: An integrative framework of analysis. Journal of Marketing Management, 18(1-2), 145-171.

Lynch Jr, J. G., Marmorstein, H., ve Weigold, M. F. (1988). Choices from sets including remembered brands: Use of recalled attributes and prior overall evaluations. Journal of Consumer Research, 15(2), 169-184.

Lynch Jr, J. G. ve Ariely, D. (2000). Wine online: Search costs affect competition on price, quality, and distribution. Marketing Science, 19(1), 83-103.

Mantel, S. P. ve Kardes, F. R. (1999). The role of direction of comparison, attribute-based processing, and attitude-based processing in consumer preference. Journal of Consumer Research, 25(4), 335-352.

Mcgoldrick, P. J., Betts, E. J. ve Wilson, A. F. (1999). Modelling consumer price cognition: Evidence from discount and superstore 
sectors. Service Industries Journal, 19(1), 171193.

Menkveld, B. G. T. (2013). Exploring credibility in electronic word-of-mouth. Unpublished master's thesis. University of Twente).

Mirtagioğlu, H., Yiğit, S., Mendeș, E., ve Mendeş, M. (2017). A Monte Carlo Simulation Study For Comparing Performances Of Some Homogeneity Of Variances Tests. Journal of Applied Quantitative Methods, 12(1), 1-11.

Monroe, K. B. (1973). Buyers' subjective perceptions of price. Journal of Marketing Research, 10(1), 70-80.

Monroe, K. B. (2003) Pricing: Making profitable decisions (3rd ed.). New York:McGraw-Hill.

Mudambi, S. M., ve Schuff, D. (2010). Research note: What makes a helpful online review? A study of customer reviews on Amazon. com. MIS Quarterly, 34, 185-200.

Nelson, P. (1970). Information and consumer behavior. Journal of political economy, 78(2), 311-329.

Nelson, P. (1974). Advertising as information. Journal of Political Economy, 82(4), 729-754.

Nunnally, J. (1978). Psychometric methods, 464-465.

Pallant, J. (2005). SPSS Survival Manual: A Step By Step Guide to Data Analysis Using SPSS for Windows Version.

Pan, Y. ve Zhang, J. Q. (2011). Born unequal: a study of the helpfulness of usergenerated product reviews. Journal of Retailing, 87(4), 598-612.

Park, D. H., Lee, J., ve Han, I. (2007). The effect of online consumer reviews on consumer purchasing intention: The moderating role of involvement. International Journal of Electronic Commerce, 11(4), 125-148.

Park, D. H. ve Lee, J. (2008). eWOM overload and its effect on consumer behavioral intention depending on consumer involvement. Electronic Commerce Research and Applications, 7(4), 386-398.

Peterson, R. A., Balasubramanian, S., ve Bronnenberg, B. J. (1997). Exploring the implications of the Internet for consumer marketing. Journal of the Academy of Marketing science, 25(4), 329-346.

Puccinelli, N. M., Chandrashekaran, R., Grewal, D., ve Suri, R. (2013). Are men seduced by red? The effect of red versus black prices on price perceptions. Journal of Retailing, 89(2), 115-125.

Scheiner, S. M. (2001). Multiple response variables and multi-species interactions. Design and analysis of ecological experiments, 99-133.

Sheffet, M. J. (1983). An experimental investigation of the documentation of advertising claims. Journal of Advertising, 12(1), 19-29.

Smith, S. M. ve Albaum, G. S. (2005). Fundamentals of marketing research. Thousand Oaks, California: Sage Publications.

Stauss, B. (1997). Global word of mouth: service bashing on the Internet is a thorny issue. Marketing Management, 6(3), 28-30.

Stigler, G. J. (1961). The economics of information. Journal of Political Economy, 69(3), 213-225.

Sujan, M., Bettman, J. R., ve Sujan, H. (1986). Effects of consumer expectations on information processing in selling encounters. Journal of Marketing Research, 23(4), 346-353.

Tabachnick, B. G. ve Fidell, L. S. (2007). Using multivariate statistics. Allyn ve Bacon/Pearson Education.

Tek, Ö. B. (1999). Pazarlama İlkeleri, Global Yönetimsel Yaklaşım, Türkiye Uygulamaları. İstanbul: Beta Basım Yayım Dağıtım A.Ş. 
Thaler, R. (1985). Mental Accounting and Consumer Choice. Marketing Science, 4 (3), 199-214.

Thamizhvanan, A. ve Xavier, M. J. (2013). Determinants of customers' online purchase intention: an empirical study in India. Journal of Indian Business Research, 5(1), 17-32.

Urbany, J. E., Bearden, W. O., ve Weilbaker, D. C. (1988). The effect of plausible and exaggerated reference prices on consumer perceptions and price search. Journal of Consumer Research, 15(1), 95-110.

Valarie, A. Z., ve Bitner, M. (2000). Services marketing: integrating customer focus across the firm. Copyright by the McGraw-Hill Education, 112.

Weathers, D., Sharma, S., ve Wood, S. L. (2007). Effects of online communication practices on consumer perceptions of performance uncertainty for search and experience goods. Journal of Retailing, 83(4), 393-401.

Williams, M. (2007). Word-of-Mouth a Definition of Communication, Elmhurst College. Web.

Winer, R. S. (1986). A reference price model of brand choice for frequently purchased products. Journal of Consumer Research, 13(2), 250-256.

Yee, N. (2006). The demographics, motivations, and derived experiences of users of massively multi-user online graphical environments. Presence: Teleoperators and virtual environments, 15(3), 309-329.

Yip, M. C. W. (2002). Presentation effects on arithmetic problem solving. Psychologia, 45(2), 90-97.

Zaichkowsky, J. L. (1985). Measuring the involvement construct. Journal of Consumer Research, 12(3), 341-352. 